\title{
Comparing Total Cost of Ownership of Electric and Conventional Motorcycles in Indonesia
}

\author{
S. M. Afraah, Y. Yuniaristanto *, W. Sutopo, M. Hisjam \\ Department of Industrial Engineering, Sebelas Maret University, Indonesia \\ Jl. Ir. Sutami no 36 A, Surakarta, (0271) 641756, Indonesia \\ * Corresponding author: yuniaristanto@ft.uns.ac.id
}

\section{ARTICLE INFO}

\section{Article history}

Received May 30, 2021

Revised August 6, 2021

Accepted August 15, 2021

Available Online August 31, 2021

Keywords

Electric Motorcycles

Conventional Motorcycles

Total Cost of Ownership

Consumer-oriented

\section{ABSTRACT}

The adoption of Electric Vehicles (EV) is one of the solutions to reduce emission problems. In Indonesia, the government targets 2.1 million Electric Motorcycles (EM) ownership in 2025. One of the keys to encouraging the EV Indonesian market is vehicle cost analysis, like Total Cost of Ownership (TCO). This study developed a TCO model to compare EM with Conventional Motorcycles (CM) in Indonesia. Data were collected from surveys and information from stakeholders. The proposed TCO model considered a battery replacement cost, which influenced the resale value of the vehicle. As a result, the TCO of EM had a more economical value than CM of $12 \%$ (IDR 3 million) on low mobility, $16 \%$ (IDR 4 million) on medium mobility, and 18\% (IDR 5.5 million) on high mobility. In addition, several scenarios were also analyzed as a study to consider providing subsidies ownership motorcycles in Indonesia.

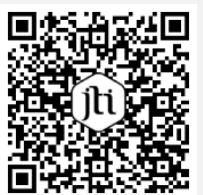

This is an open-access article under the CC-BY-SA license.

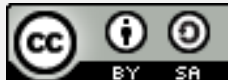

\section{Introduction}

Currently, various problems related to energy scarcity, air pollution, and greenhouse gas emissions are sweeping the world [1]. One of the most significant contributors that trigger this problem is energy consumption from vehicles' petroleum fuel, which increases CO2 emissions [2]. In 2018, the development of fueled vehicles in Indonesia increased rapidly to reach 126.5 million, consisting of $11.7 \%$ passenger cars, $0.2 \%$ bus cars, $3.8 \%$ freight cars, and $84.3 \%$ motorcycles [3]. This problem raised concerns, especially related to environmental problems. From these problems, an environmentally friendly and energy-efficient transportation solution is needed to reduce existing emissions, such as electric vehicle technology innovation and battery technology innovation [4]. In Indonesia, the existence of Presidential Regulation Number 55 of 2019 strengthens this solution concerning the Acceleration of the Battery-based Electric Motor Vehicle Program for Road Transportation as one of the government's efforts to reduce the disposal of GHG or Greenhouse Gas. Through this regulation, the government also socializes motorcycles and electric cars, followed by the issuance of 17 incentives for electric cars. In 2025, the government is also targeting as many as 2.1 million units of EMs and 2.2 thousand units of electric cars. 
Unfortunately, the population of EMs until the end of August 2020 has not reached 2,000 units, which suggested that the market share was only $0.095 \%$ of the government's target [5]. This fact indicates that the adoption of EMs in Indonesia is still very low. The low adoption rate of EMs is due to the high purchase price compared to the CMs [6]. More than half of consumers only consider purchase price when making decisions in purchasing and underestimate the sizeable cost advantage of the other costs in a period of ownership [7-9]. In addition, many factors play roles in consumer decisions in purchasing electric vehicles [10-13]. There are two classifications of these factors, namely monetary and nonmonetary. Some research usually approaches the monetary group using the Total Cost of Ownership (TCO) model. TCO is a philosophy intended to calculate the actual cost of buying a product such as a motorcycle [14]. The main objective of this TCO is to make better purchasing decisions by considering the issue of costs beyond price [15] and comparing all costs associated with owning a product over its economic life [16].

Some studies discussed the application of the TCO model for comparisons between electric and conventional vehicles. Comparing the TCO between conventional and electric cars or trucks to assess the existence of Corporate Average Fuel Economy standards [17]. Then, [18] compared the TCO of 17 car brands consisting of conventional and electric to create new business models promoting EV adoption in Singapore. [19] investigated the TCO between passenger and private cars in Belgium to maximize the RES (Renewable Energy Sources) used and cost guarantee status. One application of this TCO model is the consumer-oriented approach (TCOc), which considers all actual costs received and borne directly by consumers when using the product [15]. This TCOc consists of two types of costs, namely Capital Expenditure and Operational Expenditure. Capital Expenditure is a component of capital cost, which includes the purchase and the resale price. Meanwhile, Operational Expenditure is a cost component related to operational ownership, including taxes, insurance, maintenance, energy consumption, and discount rates [20]. Some previous research ignored several cost components in calculating the TCO value and explained in Table 1.

Table 1. State of The Art of This Research

\begin{tabular}{|c|c|c|c|c|c|c|c|c|c|c|c|}
\hline \multirow[b]{2}{*}{ No } & \multirow[b]{2}{*}{ Reference } & \multicolumn{4}{|c|}{ Capital Expenditure } & \multicolumn{5}{|c|}{ Operational Expenditure } & \multirow[b]{2}{*}{ 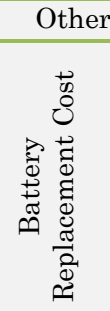 } \\
\hline & & 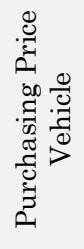 & 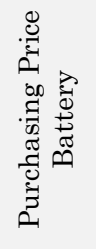 & 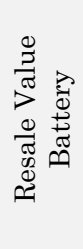 & 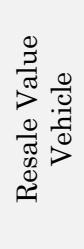 & 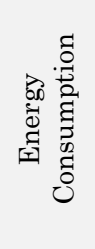 & 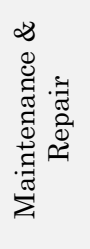 & 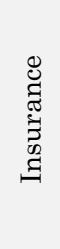 & 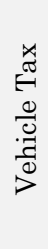 & 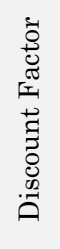 & \\
\hline 1 & $\begin{array}{l}\text { Mitropoulos, et al. [21], } \\
\text { Hagman, et al. [22] }\end{array}$ & $\mathrm{X}$ & - & $\mathrm{X}$ & - & $\mathrm{X}$ & $\mathrm{X}$ & $\mathrm{X}$ & $\mathrm{X}$ & - & - \\
\hline 2 & Bubeck, et al. [23] & $\mathrm{X}$ & $\mathrm{X}$ & $\mathrm{X}$ & - & $\mathrm{X}$ & $\mathrm{X}$ & $\mathrm{X}$ & $\mathrm{X}$ & $\mathrm{X}$ & - \\
\hline 3 & Kerdlap and Gheewala [24] & $\mathrm{X}$ & - & $\mathrm{X}$ & $\mathrm{X}$ & $\mathrm{X}$ & $\mathrm{X}$ & - & - & $\mathrm{X}$ & - \\
\hline 4 & Babin, et al. [25] & $\mathrm{X}$ & $\mathrm{X}$ & $\mathrm{X}$ & $\mathrm{X}$ & $\mathrm{X}$ & $\mathrm{X}$ & - & - & - & - \\
\hline 5 & Letmathe and Suares [20] & $\mathrm{X}$ & $\mathrm{X}$ & $\mathrm{X}$ & $\mathrm{X}$ & $\mathrm{X}$ & $\mathrm{X}$ & $\mathrm{X}$ & $\mathrm{X}$ & $\mathrm{X}$ & - \\
\hline 6 & $\begin{array}{l}\text { Palmer, et al. [26], } \\
\text { Sherrington and Moran [27], } \\
\text { Danielis, et al. [28] }\end{array}$ & $\mathrm{X}$ & - & $\mathrm{X}$ & - & $\mathrm{X}$ & $\mathrm{X}$ & $\mathrm{X}$ & $\mathrm{X}$ & $\mathrm{X}$ & - \\
\hline 7 & Millard-Ball [17] & $\mathrm{X}$ & - & $\mathrm{X}$ & - & $\mathrm{X}$ & $\mathrm{X}$ & $\mathrm{X}$ & $\mathrm{X}$ & $\mathrm{X}$ & - \\
\hline 8 & Pavan, et al. [29] & $\mathrm{X}$ & - & $\mathrm{X}$ & - & $\mathrm{X}$ & $\mathrm{X}$ & & $\mathrm{X}$ & - & - \\
\hline 9 & Riyanto, et al. [30] & $\mathrm{X}$ & - & $\mathrm{X}$ & - & $\mathrm{X}$ & $\mathrm{X}$ & $\mathrm{X}$ & $\mathrm{X}$ & $\mathrm{X}$ & - \\
\hline 10 & Kumar and Chakrabarty [31] & $\mathrm{X}$ & - & $\mathrm{X}$ & - & $\mathrm{X}$ & $\mathrm{X}$ & - & - & $\mathrm{X}$ & - \\
\hline 11 & This Research & $\mathrm{X}$ & $\mathrm{X}$ & $\mathrm{X}$ & $\mathrm{X}$ & $\mathrm{X}$ & $\mathrm{X}$ & $\mathrm{X}$ & $\mathrm{X}$ & $\mathrm{X}$ & $\mathrm{X}$ \\
\hline
\end{tabular}


From Table 1, the findings of this research consisted of two points. First, this study added complete components of consumer-oriented and the cost of replacing the battery taking into account the user's charging behavior. When the battery exceeds the economic life of the charging cycle, its capacity will decrease to $70 \%$ [32]. Several previous studies in this cost component only considered the length of time as a determinant of the economic life of the battery [24, 29, 33]. However, most batteries were equipped with a battery management system to see the number of charge cycles to determine the economic life, which was very dependent on the user's behavior [34]. Second, this research was considered necessary since the output could be a beneficial study for the users. The benefit covered the description in detail. In addition, the purchase included the vehicle's price, considering the total cost during the ownership period [35].

This research was a study on EVs in Indonesia, especially focusing on Ems. Motorcycles are the main transportation in Indonesia [34]. Some previous researches developed an adoption intention model from independent and dependent factors. In contrast, this research was intended to develop a total cost of ownership model focusing on the monetary factors. This study also aimed to develop a consumer-oriented TCO model and compare EM and CM's TCO value. The urgency of this research was to help accelerate the adoption of EM in the Indonesian market to achieve the government's target in 2025 of 2.1 million motorcycles. In addition, this research was an effort to conserve the dwindling fuel oil and reduce the high carbon emissions in big cities in Indonesia.

\section{Methods}

The research procedure of this research is presented in Fig. 1. The research's five (5) main stages included object definition, data collection (primary and secondary data), TCO Model Development, TCO Value Calculation, and Sensitivity Analysis. In addition, a complete description of the Research Procedure is presented in the following sub-section.

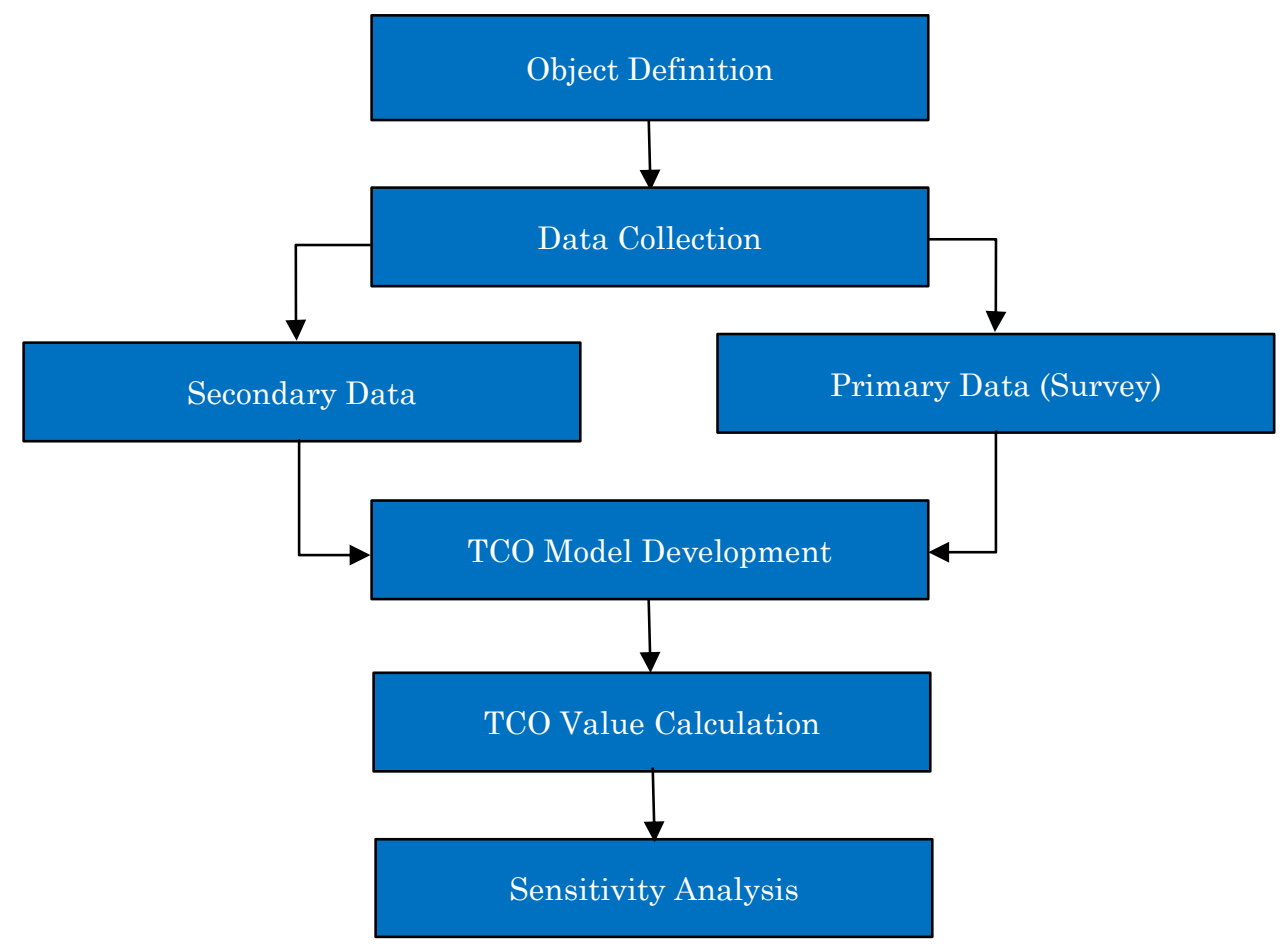

Fig. 1. TCO Research Procedure 


\subsection{Object Definition}

This research selected the motorcycles vehicle based on the best Conventional Motorcycles (CM) brands performance based on Top Brand Award [36]. The determined Electric Motorcycle (EM) brands had similar body shapes, motorcycle, foot, and tire sizes. In this study, the samples were obtained from the automotive website. It is used to compare the TCO of the CM and EM. Each attribute type was grouped into primary data directly influenced by users and required a survey as the study tool. The secondary data were taken from the government regulations.

\subsection{Data Collection}

Primary data were obtained from survey results for attributes user behavior to get an accurate result of TCO [37]. This research collected data using questionnaires from the $\mathrm{CM}$ and EM users. The priority of respondents consists of respondents with the province domiciled with the highest level of motorcycle sales in Indonesia. This data collection divided the survey into three sections with the attributes of the questions described in Table 2. If a user did not meet one or more of the screening criteria, then the data from that user were not considered valid. The result of the survey was then processed using analytical methods with statistical analysis. This research also grouped the respondent into three types of mobility (low, medium, and high mobility) based on the daily mileage, according to Bubeck, et al. [23].

Secondary data were collected from stakeholders' documents, namely the government, manufacturers, distributors, motorcycle agents, and previous studies. The secondary data are shown in Table 3 . The total responses matched with the requirements for processing data consisted of $118 \mathrm{CMs}$ respondents and $74 \mathrm{EMs}$ respondents.

Table 2. Attribute of Survey

\begin{tabular}{|c|c|c|}
\hline Screening [38] & Socio-demographic [38] & User behavior $[20,23,24,30,39]$ \\
\hline $\begin{array}{l}\text { People who are } \geq 17 \\
\text { years old } \\
\text { Having a SIM C } \\
\text { One of the decision- } \\
\text { makers } \\
\text { to replace or buy } \\
\text { motorcycles } \\
\text { CM or EM User }\end{array}$ & $\begin{array}{l}\text { Domicile } \\
\text { Age } \\
\text { Gender } \\
\text { Marital Status } \\
\text { Occupation } \\
\text { Last Education-al Level } \\
\text { Monthly Income Level }\end{array}$ & $\begin{array}{l}\text { Vehicle brand } \\
\text { Payment system } \\
\text { Period of ownership } \\
\text { Performance } \\
\text { Mileage } \\
\text { Fuel type (for CM) and Charging place } \\
\text { (for EM) } \\
\text { Energy charging frequency (for EM) } \\
\text { Type of parts serviced } \\
\text { Service cost } \\
\text { Parking cost } \\
\text { Insurance cost }\end{array}$ \\
\hline
\end{tabular}

\subsection{TCO Model Development}

This study developed the model proposed by [30] by adding the Battery Replacement Cost (BR) component as suggested in [40]. The formula for ConsumerOriented TCO (TCOc) is shown in Equation (1). Resale Value (RV), Operating Expenditure (Copex), and Battery Replacement Cost (BR) models are presented in Equations (2), (3), and (4), respectively. Details of the TCOc, RV, Copex, and BR models are described in the following sub-section. 
Table 3. Assumptions from Secondary Data used in this study

\begin{tabular}{|c|c|c|c|c|c|}
\hline \multirow{2}{*}{\multicolumn{6}{|c|}{ Assumntion }} \\
\hline & Value & & Assumption & & Unit \\
\hline Battery life & 1,000 & Charge cycle & $\begin{array}{l}\text { Vehicle } \\
\text { depreciation }\end{array}$ & 7.08\%/year & $\begin{array}{l}\text { Processings } \\
\text { data result }\end{array}$ \\
\hline Discount rate & 12.78 & $\begin{array}{l}\text { Sum of } \\
\text { inflation and } \\
\text { consumption } \\
\text { rate }(\%)\end{array}$ & Fuel Cost & 7,650 & IDR/liters \\
\hline $\begin{array}{l}\text { Interest } \\
\text { Charged }\end{array}$ & $0.65 \%$ & \multirow{2}{*}{$\begin{array}{l}\text { Loans to banks } \\
\text { (purchases on } \\
\text { credit) }\end{array}$} & \multirow{2}{*}{$\begin{array}{l}\text { Percentage } \\
\text { increase in } \\
\text { energy } \\
\text { consumption }\end{array}$} & $2 \%($ for $\mathrm{CM})$ & per years \\
\hline Tenor payment & 36 month & & & $\begin{array}{l}0.03 \% \text { (for } \\
\text { EM) }\end{array}$ & $\begin{array}{l}\text { per } \\
\text { charging }\end{array}$ \\
\hline \multirow[b]{2}{*}{$\begin{array}{l}\text { Battery } \\
\text { depreciation }\end{array}$} & \multirow[b]{2}{*}{$\begin{array}{l}8 \% / \text { year } \\
11 \% / \text { year } \\
14 / \text { year }\end{array}$} & Low mobility & Electricity Cost & 1,650 & IDR/kWh \\
\hline & & $\begin{array}{l}\text { Moderate } \\
\text { mobility } \\
\text { High mobility }\end{array}$ & & & \\
\hline
\end{tabular}

$T C O_{C}=P P+\sum_{t=1}^{j} \frac{C_{o p e x}}{(1+r)^{t}}-R V(1+r)^{-j}+B R$

$R V=\left(1-d_{V}\right)^{n} x P P+C_{B}$

$C_{\text {opex }}=C_{E C}+C_{M R}+C_{I N}+C_{T A}+C_{O F}+C_{I P}$

$B R=\sum_{t=i}^{f i<j} \frac{\left(B P-C_{B}\right)}{(1+r)^{t}}$

\subsubsection{TCO Consumer-Oriented (TCOc)}

The Purchased Price (PP) is the OTR (on the road) price, which includes the net price of the purchase of a vehicle, including tax and other administrative costs. This price also decreases over time, such as the effect of the age of a motorcycle. The purchase price data are based on the official automotive website. Then, a discount rate (r) is an essential component in the calculation because it affects the fluctuation of prices. Thus, the results of calculating costs at a certain time can be converted to the present value.

\subsubsection{Resale Value (RV)}

In this research, TOCc calculation research also implemented a resale value formula [41]. It was affected by the depreciation value (DV) during the ownership period (n). Then, the calculation of the resale value of EMs was calculated separately between the battery and the vehicle. Meanwhile, the calculation of the battery resale price (CB) was similar to RV. However, the value depreciation of the battery was according to the type of vehicle mobility.

\subsubsection{Operating Expenditure (Copex)}

The cost of annual operating expenditure (Copex) consists of the sum of all cash payments, such as cost of energy consumption (CEC), cost of maintenance and repair (CMR), cost of insurance (CIN), cost of tax vehicle (CTA), other fixed cost or parking cost (COF), and cost of interest payment (CIP). CEC and CMR were the cost variables as they were affected by Annual Kilometers Travelled (AKT), using the Equations (5) and (6), respectively. 


$$
\begin{aligned}
& C_{E C}=\left(100 \%+k_{C M}(t-1)\right) x \frac{A K T \times C_{E}}{E C} \\
& C_{M R}=C_{R}+\left(C_{M} \times \mathrm{AKT}\right)
\end{aligned}
$$

Where,

$k_{C M}$ : Percentage increase in energy consumption

$\mathrm{t} \quad:$ Year, $\mathrm{t} \in\{1, \ldots$, period of ownership)

EC : Energy Consumption Needs

$C_{E} \quad$ : Energy Cost

$C_{R} \quad:$ Repair Cost

$C_{M}$ : Maintenance Cost

\subsubsection{Battery Replacement Cost (BR)}

The economic life of the battery in this study was 1000 cycles. Then the battery capacity decreased to $70 \%$ and required replacement. The difference of BR between the purchase price $(B P)$ and the battery's resale price $(C B)$ was relevant to the discount rate in the year of replacement. The higher the charging frequency, the faster the economic life of the battery ran out. The battery replacement period ( $i)$ was obtained by dividing the economic life of the battery $(b)$ by the frequency of charging $(f F)$. Meanwhile, the battery replacement sequence $(f)$ was obtained by dividing the length of ownership $(n)$ by the battery replacement period $(i)$.

\subsection{TCO Value Calculation}

Primary and secondary data were used as input values in the TCO model that was developed. Based on the calculation results, it could be shown that the comparison of TCO EM and CM values was superior and could be used as a basis for consideration.

\subsection{Sensitivity Analysis}

The sensitivity analysis of the TCO model was selected to see the model's sensitivity to changes in existing parameters. It was acted as the basis for determining policy recommendations. The model developed in this study also could be used to see the effect of fiscal and non-fiscal policies that were possible. For example, to look at the impact of decreasing the annual tax or parking fee, this study provided the option to give subsidies in decreasing or erasing tax, parking fee, or the other subsidy. With that, the effect of policy on TCO was perceived.

The data input used in this analysis was the type of user with low mobility, with a defined work period of 6,9 , and 12 years based on a survey of respondents where $14 \%$ of the battery has a service life of $\geq 7$ years.

\section{Results and Discussion 3.1 Results of Survey}

The social factors based on the survey results showed that most CMs respondents had one unit of motorcycles with a level of environmental awareness in the very caring category. Meanwhile, most of the respondents of EMs owned more than one unit of motorcycles with a level of environmental awareness in the very caring category. Therefore, based on the survey results, the respondent profile is described in Table 4. 
Table 4. Respondent Profile based on the survey

\begin{tabular}{llll}
\hline Attribute & Value & Attribute & Value \\
\hline & $\begin{array}{l}\text { Low mobility (14km per } \\
\text { day) }\end{array}$ & & $\begin{array}{l}\text { Low Mobility (IDR 2,000.00) } \\
\text { Medium Mobility (IDR }\end{array}$ \\
$\begin{array}{l}\text { Daily travel } \\
\text { distance }\end{array}$ & $\begin{array}{l}\text { Medium mobility (28km per } \\
\text { day) }\end{array}$ & $\begin{array}{l}\text { Daily } \\
\text { parking fee }\end{array}$ & $\begin{array}{l}\text { 2,000.00) } \\
\text { High Mobility (IDR 4,000.00 } \\
\text { for CM; IDR 2,000.00 for }\end{array}$ \\
& $\begin{array}{l}\text { High mobility (56km per } \\
\text { day) }\end{array}$ & & EM) \\
\hline $\begin{array}{l}\text { Frequency of } \\
\text { charging energy } \\
\text { (for EM) }\end{array}$ & $\begin{array}{l}\text { Low mobility (104 cycles) } \\
\text { Medium mobility (156 }\end{array}$ & Maintenance & $\begin{array}{l}\text { EM: IDR 70,000.00 per } \\
\text { cycles) }\end{array}$ \\
$\begin{array}{llll}\text { Ownership } \\
\text { period }\end{array}$ & High mobility (208 cycles) & Cost & CM: IDR 119,000.00 per \\
$\begin{array}{l}\text { Insurance } \\
\text { premium }\end{array}$ & Six years & & \\
& $1.5 \%$ & Repair Cost & EM: IDR 7.34 / km \\
& & & CM: IDR 12.5 / km \\
\hline
\end{tabular}

\subsection{TCOc Value Calculation Results}

Based on Table 5, the purchase price and resale value of CM were lower than EM, while CM's operating costs were higher than EM. Through calculations using the formulation model 1, the TCOc value in Table 1 showed that EM TCOc was more efficient than CM. These results are consistent with similar research in Indonesia, which compares the cost of owning an electric car, where the value of EV (Electric Vehicle) is proven to be more efficient than CV. Based on Table 5, the CM value also suggested a value that tended to be higher than the EM value for all types of mobility. So, the higher the distance traveled in every type of mobility, the higher the cost savings in EM, increasing significantly.

Table 5. TCOc Value Calculation Results

\begin{tabular}{lllllll}
\hline \multirow{2}{*}{ Item } & \multicolumn{2}{l}{$\begin{array}{l}\text { Low Mobility } \\
\text { (IDR '000) }\end{array}$} & \multicolumn{3}{l}{$\begin{array}{l}\text { Moderate Mobility } \\
\text { (IDR '000) }\end{array}$} & \multicolumn{2}{l}{$\begin{array}{l}\text { High Mobility } \\
\text { (IDR '000) }\end{array}$} \\
\cline { 2 - 8 } & CM & EM & CM & EM & CM & EM \\
\hline Purchase Price & $17,650.00$ & $18,990.00$ & $17,650.00$ & $18,990.00$ & $17,650.00$ & $18,990.00$ \\
\hline Operational Price & $10,732.82$ & $8,642.44$ & $13,702.18$ & $10,194.77$ & $19,428.81$ & $13,266.25$ \\
\hline Resale Value & $5,520.87$ & $7,708.03$ & $5,520.87$ & $7,389.12$ & $5,520.87$ & $8,447.61$ \\
\hline $\begin{array}{l}\text { Battery } \\
\text { Replacement }\end{array}$ & - & - & - & - & - & $2,203.26$ \\
\hline TCO - Consumer & $22,861.95$ & $19,924.41$ & $25,831.32$ & $21,795.65$ & $31,557.94$ & $26,011.90$ \\
\hline
\end{tabular}

The purchase price value had the same value for all types of mobility because the cost component was a one-time cost that was influenced by the withdrawn value using a discount factor for a particular year. However, while the CM resale value also had the same value, the EM had a different value for each type of mobility. The difference was in the remaining value of the battery at the end of ownership, which affected the resale value. As with high mobility, the resale value had a higher value than other types of mobility, because, in high mobility, there was a cost of replacing the battery. After all, the cycle life of the battery ran out and required replacement. Thus, at the end of ownership, the residual value of the battery had a higher value as it was a new battery and was added to the resale value of the EM. This component was essential to consider because, in previous 
studies, such as in Riyanto, et al. [30], they did not consider the value of the remaining battery in the TCO calculation. Furthermore, the battery was still in the warranty period.

Therefore, based on Table 5, the component cost of replacing the battery for low mobility and moderate mobility was IDR 0.00 because the charging frequency during its lifetime had not exceeded the economic life of the battery, so it did not need replacing. At the same time, high mobility requires one-time battery replacement because high mileage results in higher charging frequency and influences battery economy during its lifetime.
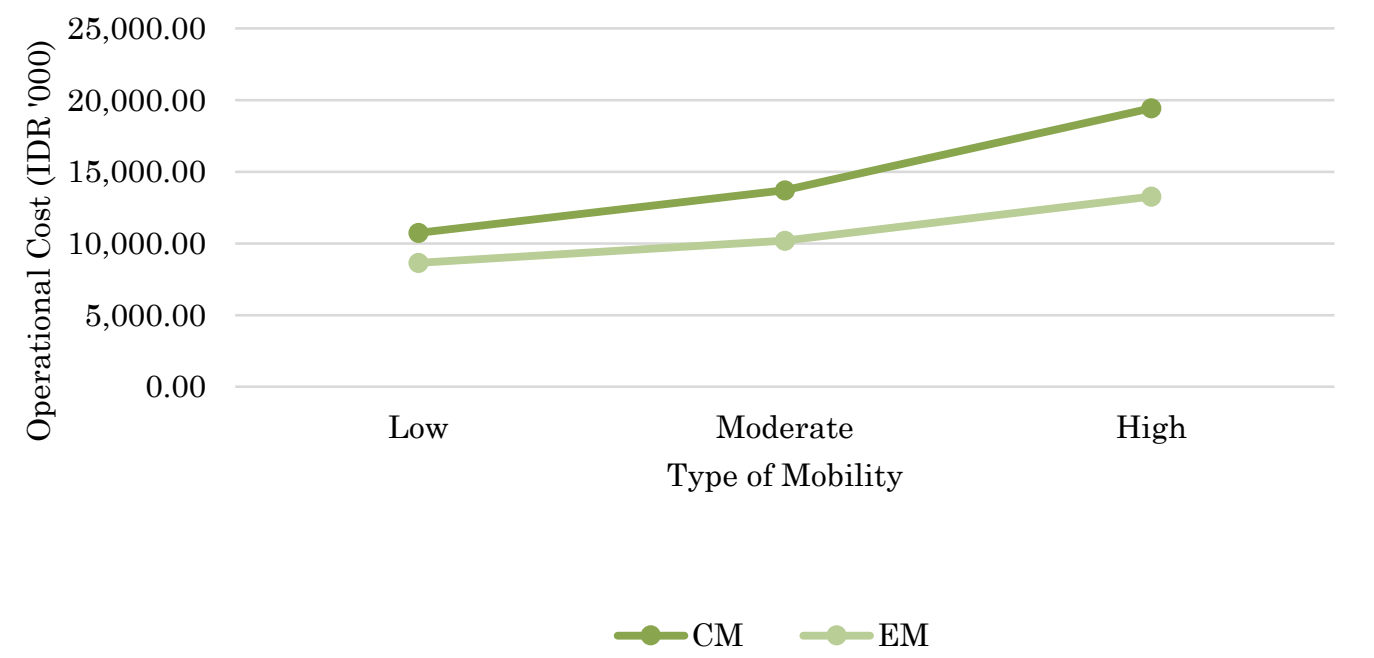

Fig. 2. Comparison of Operational Cost

Based on Fig. 2, the cost component that affected the difference between EM and CM consisted of operational costs, namely the energy consumption cost, repairs, and maintenance costs, which the distance traveled by the user influenced. Table 6 displays the CM respondents with the type of work. Meanwhile, EM respondents mainly consisted of respondents with low and medium mobility types. Based on these facts, CM could be used for all users. At the same time, EM was more suitable for low and medium-mobility users who only traveled within the city.

Table 6. The Types of Work in Every Mobility

\begin{tabular}{lll}
\hline Low Mobility & Medium Mobility & High Mobility \\
\hline Students & Private employees & Drivers \\
Housewives & Entrepreneurs & Couriers \\
& Job seekers & Laborers or construction \\
& & workers
\end{tabular}

In addition to energy consumption costs, the cost components that affected operational cost savings in EM were repair and maintenance costs explained in the detailed data in Table 4. This cost consisted of routine service costs and spare parts replacement costs. CM periodic service fees had a percentage of $41 \%$ higher than EM service fees because EM did not require oil changes in engine components. As for the cost of replacing spare parts, considering the components that require repair according to the 
replacement period. EM had a lower replacement cost because it only required the replacement of brake pads and belts and did not require replacing the oil filter as a filter for engine combustion dirt which had a replacement period of every $30,000 \mathrm{~km}$, such as CM. Thus, the ease of maintenance of EM provided a service cost savings of IDR. $5.16 / \mathrm{km}$ compared to CM [42].

The method in this study was seen as beneficial compared to previous studies that used input data based on assumptions and similar research data [43, 44]. In addition, because this study considered actual data according to each user's behavior and the remaining value of the battery outside the warranty period, it resulted in a more accurate TCO value and according to actual conditions.

\subsection{Sensitivity Analysis}

Sensitivity analysis was intended to see the model's sensitivity to changes in existing parameters [45]. Based on Fig. 3, during the six-year ownership period and nine years, the savings on TCO-EM were $9 \%$, while in the 12 years of ownership period, the value of the TCO-EM savings decreased 1\% compared to TCO-CM. Therefore, with the higher duration of ownership, the use of EM had a value that remained superior but not too significant. This condition was consistent with the research in Indonesia, which implemented a similar scenario on electric cars [30].

One of the reasons for the insignificant difference in TCOc value due to the increase in ownership period in this condition was the battery replacement factor, which was user mobility. The higher user's mobility, the higher frequency of charging the battery, and it decreases the economic life of the battery. Therefore, when a battery passes its useful life, it reduces capacity when used, and it becomes ineffective. In addition, the high battery price meant that the savings in EV TCO value were insignificant. Several similar studies in Thailand [24] have also shown a similar case in battery replacement costs because of the absence of regulations regarding battery recycling efficiency and the minimum number of business actors engaged in this field [46].

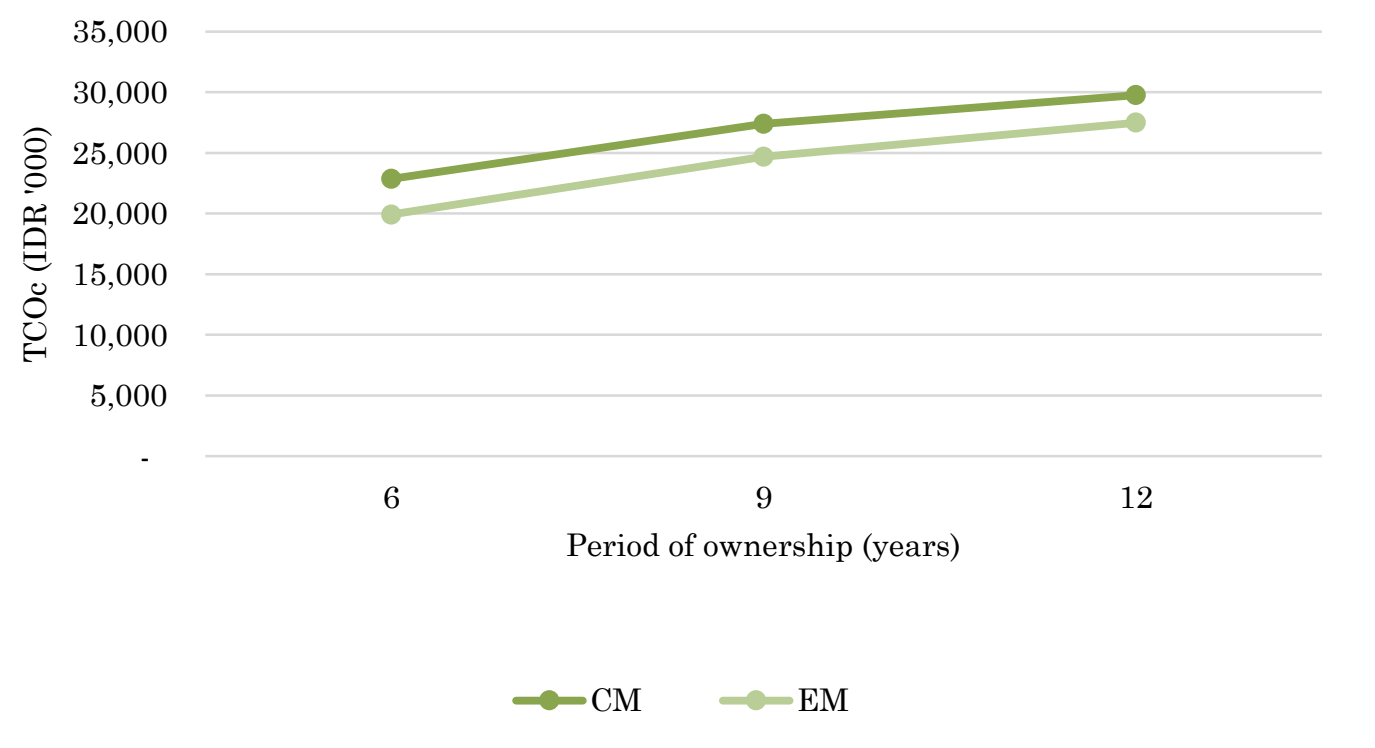

Fig. 3. Sensitivity Analysis of Duration Ownership 


\subsection{Policy Recommendation}

Based on the calculation of the TCOc value of all types of mobility, the TCOc value of CM had a higher value than EM. If some subsidy was applied in EM, TCOc EM could be more competitive than CM. It is hoped to provide more operational cost savings for EM than CM and encourage consumer purchasing decisions towards EM. This scenario was shown in Fig. 4, where the existence of a tax subsidy reduced the value of EM TCOc by 2.9\% (IDR 627,000). As discussed by the government, exemption from parking fees could also be one of the subsidies provided to further reduce the value of TCOc in EM. However, in this case, the government also needs to consider subsidies for the inclusion of parking attendants as compensation for the free parking policy for EMs in Indonesia. This scenario is shown in Fig. 5, where parking free reduced TCOc EM by 15\% (2.9 million).

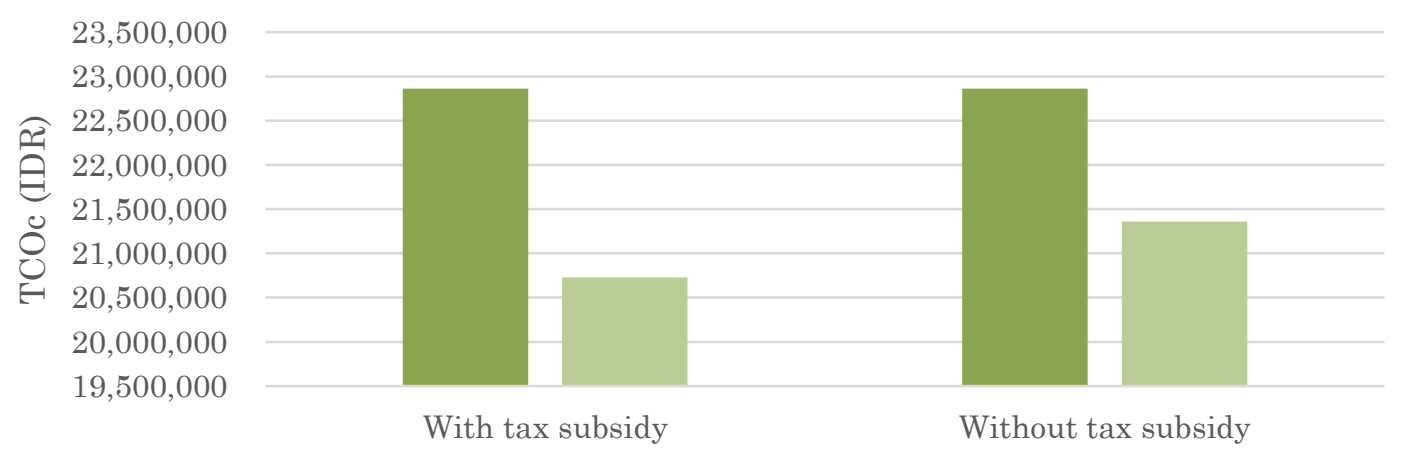

Scenario

$\square \mathrm{CM} \quad \mathrm{EM}$

Fig. 4. The Influence of Tax Subsidy to TCOc in Low Mobility

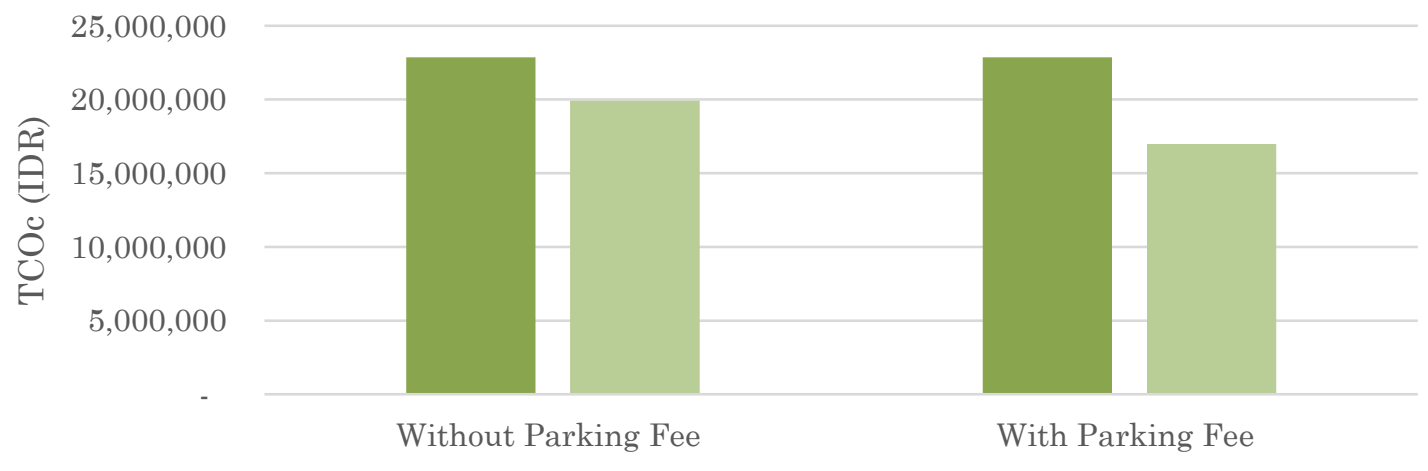

Scenario

$\square \mathrm{CM} \quad \mathrm{EM}$

Fig. 5. The influence of Free Parking Fee on TCOc in Low Mobility 
The reduction in TCOc in EM through the subsidy provision scenario, both on tax costs, parking fees, and other operational costs, could be taken into consideration by policymakers so that the public as users know in more detail about the amount of savings in EM use. In addition, replacement battery cost, which affected saving TCOc EM value, could be overcome with the support of infrastructures. It was presented in the Public Electric Vehicle Charging Station (SPKLU) with fast charging mode and General Electric Vehicle Battery Exchange Station (SPBKLU), which was realized immediately to overcome the impact of the disruptive decrease in battery capacity when driving. Policymakers also needed to review the battery recycling technology to reduce the purchase of existing batteries [47]. Hence, providing subsidies and supporting infrastructure, it was hoped to stimulate public interest to start shifting from CM to EM, which was more environmentally friendly and saved operating costs. It could also be a consideration for agents or manufacturers in determining the appropriate market segment and in determining suppliers for technology development to determine prices that can compete with CM products $[48,49]$.

\section{Conclusion}

The TCO model developed consisted of the sum of the TCO value of consumer orientation capital expenditure (vehicle investment costs, battery investment costs, vehicle resale prices, battery resale prices), operational expenditure (energy consumption costs, repair and maintenance costs, insurance costs, annual taxes, interest payments, parking fees), and battery replacement costs. When the battery exceeds the economic life of the charge cycle, the capacity would be reduced by up to $70 \%$. In addition, the battery replacement process affected the remaining value of the battery at the end of ownership. Therefore, it caused a difference in the resale value. Based on the calculation results, the TCOc value for six years was directly borne by the user. Furthermore, the calculation results showed that the EM value had a lower average value percentage. There were savings compared to $\mathrm{CM}$ of $12 \%$ (IDR 3 million) on low mobility, 16\% (IDR 4 million) on medium mobility, and 18\% (IDR 5.5 million) on high mobility. Finally, this research allowed the users to know that the purchase decision did not only consider the purchase price; it incurred total cost during the ownership period of the vehicle that was also considered.

Electric motorcycle manufacturers needed to understand the characteristics of the intended target market to increase sales [50]. Although not fully used as a marketing tool, education about TCO regarding the importance of understanding the value of TCO compared to the selling price offered could be conveyed by producers to consumers when they make direct offers. In addition, policy scenarios were needed in fiscal and non-fiscal to support the adoption of electric motorcycles and TCO value to be more competitive. It could encourage the achievement of the government's target, where there are as many as 2.1 million electric motorcycle owners by 2025 .

Future research may consider more comprehensive components, such as the benefits of EV in terms of benefits in addition to the advantages of cost of ownership. In addition, the TCO component can also consider broader cost components such as external costs with an environmental or social orientation due to the impact of their use.

\section{Data Availability}

All data generated or analyzed during this study are included in this article. 


\section{Declarations}

Author contribution: Conceptualization is performed by Y. Yuniaristanto and W. Sutopo; methodology is carried out by Y. Yuniaristanto; data processing is performed by S. M. Afraah; validation is carried out by Y. Yuniaristanto and W. Sutopo; formal analysis is performed by S. M. Afraah and Y. Yuniaristanto; writing paper is performed by S. M. Afraah, Y. Yuniaristanto, W. Sutopo, and M. Hisjam; funding acquisition by M. Hisjam and , Y. Yuniaristanto. All authors read and approved the final paper.

Funding statement: This research was funded by Fundamental Research Grant from The Institution of Research and Community Services of Universitas Sebelas Maret with a contract no: 260/UN27.22/HK.07.00/2021

Conflict of interest: The authors declare no conflict of interest.

Additional information: No additional information is available for this paper.

\section{Acknowledgment}

The researcher would like to thank the Institution of Research and Community Services of Universitas Sebelas Maret for supporting the research. In addition, the researcher would also like to extend their gratitude to the Logistic and business systems Laboratory for providing the facilities.

\section{References}

[1] Y.-N. Sang and H. A. Bekhet, "Modelling electric vehicle usage intentions: an empirical study in Malaysia," Journal of Cleaner Production, vol. 92, pp. 75-83, 2015. https://doi.org/10.1016/j.jclepro.2014.12.045.

[2] N. S. Tanwir and M. I. Hamzah, "Predicting Purchase Intention of Hybrid Electric Vehicles: Evidence from an Emerging Economy," World Electric Vehicle Journal, vol. 11, no. 2, 2020. https://doi.org/10.3390/wevj11020035.

[3] B. P. Statistik, "Perkembangan Jumlah Kendaraan Bermotor Menurut Jenis, 19492016," Badan Pusat Statistik, Jakarta, 20212018. https://www.bps.go.id/linkTableDinamis/view/id/1133.

[4] W. Sutopo, R. W. Astuti, A. Purwanto, and M. Nizam, "Commercialization model of new technology lithium ion battery: A case study for smart electrical vehicle," in 2013 Joint International Conference on Rural Information \& Communication Technology and Electric-Vehicle Technology (rICT \& ICeV-T), 2013, pp. 1-5. http://doi.org/10.1109/rICT-ICeVT.2013.6741511.

[5] S. M. Afraah, Y. Yuniaristanto, W. Sutopo, and M. Hisjam, "Comparing Total Cost of Ownership of Electric Motorcycles and Conventional Motorcycles in Indonesia," $\begin{array}{llllll}\text { Jurnal Teknik Industri, } & \text { vol. } 22, \quad \text { no. } 2,\end{array}$ https://ejournal.umm.ac.id/index.php/industri/article/view/16717.

[6] O. Egbue and S. Long, "Critical Issues in the Supply Chain of Lithium for Electric Vehicle Batteries," Engineering Management Journal, vol. 24, no. 3, pp. 52-62, 2012. http://doi.org/10.1080/10429247.2012.11431947.

[7] B. Lane and S. Potter, "The adoption of cleaner vehicles in the UK: exploring the consumer attitude-action gap," Journal of Cleaner Production, vol. 15, no. 11, pp. 1085-1092, 2007. https://doi.org/10.1016/j.jclepro.2006.05.026.

[8] R. M. Krause, S. R. Carley, B. W. Lane, and J. D. Graham, "Perception and reality: Public knowledge of plug-in electric vehicles in 21 U.S. cities," Energy Policy, vol. 63, pp. 433-440, 2013. https://doi.org/10.1016/j.enpol.2013.09.018. 
[9] X. Zhang, K. Wang, Y. Hao, J.-L. Fan, and Y.-M. Wei, "The impact of government policy on preference for NEVs: The evidence from China," Energy Policy, vol. 61, pp. 382-393, 2013. https://doi.org/10.1016/j.enpol.2013.06.114.

[10] N. Berkeley, D. Bailey, A. Jones, and D. Jarvis, "Assessing the transition towards Battery Electric Vehicles: A Multi-Level Perspective on drivers of, and barriers to, take up," Transportation Research Part A: Policy and Practice, vol. 106, pp. 320-332, 2017. https://doi.org/10.1016/j.tra.2017.10.004.

[11] J. J. Gómez Vilchez and C. Thiel, "The Effect of Reducing Electric Car Purchase Incentives in the European Union," World Electric Vehicle Journal, vol. 10, no. 4, 2019. https://doi.org/10.3390/wevj10040064.

[12] T. Hoppe, M. M. van den Berg, and F. H. J. M. Coenen, "Reflections on the uptake of climate change policies by local governments: facing the challenges of mitigation and adaptation," Energy, Sustainability and Society, vol. 4, no. 1, p. 8, 2014. https://doi.org/10.1186/2192-0567-4-8.

[13] M. E. Biresselioglu, M. Demirbag Kaplan, and B. K. Yilmaz, "Electric mobility in Europe: A comprehensive review of motivators and barriers in decision making processes," Transportation Research Part A: Policy and Practice, vol. 109, pp. 1-13, 2018. https://doi.org/10.1016/j.tra.2018.01.017.

[14] L. M. Ellram, "Total cost of ownership," International Journal of Physical Distribution \& Logistics Management, vol. 25, no. 8, pp. 4-23, 1995. https://doi.org/10.1108/09600039510099928.

[15] L. M. Ellram and S. Siferd, "Total cost of ownership: a key concept in strategic cost management decisions," Materials Engineering, vol. 19, no. 1, pp. 55-84, 19981998.

[16] S. Bickert and W. Kuckshinrichs, "Market integration of electric mobility: Analyzing economic efficiency and costs for consumers," in ENERDAY, 6th Conference on Energy Economics and Technology, Technische Universität, Dresden, 08, April 2011, Dresden, Germany, 2011, p. 20: Institute of Energy and Climate Research.

[17] A. Millard-Ball, "The autonomous vehicle parking problem," Transport Policy, vol. 75, pp. 99-108, 2019. https://doi.org/10.1016/j.tranpol.2019.01.003.

[18] V. Nian, M. P. Hari, and J. Yuan, "A new business model for encouraging the adoption of electric vehicles in the absence of policy support," Applied Energy, vol. 235, pp. 1106-1117, 2019. https://doi.org/10.1016/j.apenergy.2018.10.126.

[19] L. Vanhaverbeke, D. Schreurs, Q. D. Clerck, M. Messagie, and J. V. Mierlo, "Total cost of ownership of electric vehicles incorporating Vehicle to Grid technology," in 2017 Twelfth International Conference on Ecological Vehicles and Renewable Energies (EVER), 2017, pp. 1-6. http://doi.org/10.1109/EVER.2017.7935931.

[20] P. Letmathe and M. Suares, "A consumer-oriented total cost of ownership model for different vehicle types in Germany," Transportation Research Part D: Transport and Environment, vol. 57, pp. 314-335, 2017. https://doi.org/10.1016/j.trd.2017.09.007.

[21] L. K. Mitropoulos, P. D. Prevedouros, and P. Kopelias, "Total cost of ownership and externalities of conventional, hybrid and electric vehicle," Transportation Research Procedia, vol. 24, pp. 267-274, 2017. https://doi.org/10.1016/j.trpro.2017.05.117.

[22] J. Hagman, S. Ritzén, J. J. Stier, and Y. Susilo, "Total cost of ownership and its potential implications for battery electric vehicle diffusion," Research in Transportation Business \& Management, vol. 18, pp. 11-17, 2016. https://doi.org/10.1016/j.rtbm.2016.01.003.

[23] S. Bubeck, J. Tomaschek, and U. Fahl, "Perspectives of electric mobility: Total cost of ownership of electric vehicles in Germany," Transport Policy, vol. 50, pp. 63-77, 2016. https://doi.org/10.1016/j.tranpol.2016.05.012. 
[24] P. Kerdlap and S. H. Gheewala, "Electric motorcycles in Thailand: A life cycle perspective," Journal of Industrial Ecology, vol. 20, no. 6, pp. 1399-1411, 2016. https://doi.org/10.1111/jiec.12406.

[25] A. Babin, N. Rizoug, T. Mesbahi, D. Boscher, Z. Hamdoun, and C. Larouci, "Total Cost of Ownership Improvement of Commercial Electric Vehicles Using Battery Sizing and Intelligent Charge Method," IEEE Transactions on Industry Applications, vol. 54, no. 2, pp. 1691-1700, 2018. http://doi.org/10.1109/TIA.2017.2784351.

[26] K. Palmer, J. E. Tate, Z. Wadud, and J. Nellthorp, "Total cost of ownership and market share for hybrid and electric vehicles in the UK, US and Japan," Applied Energy, vol. 209, pp. 108-119, 2018. https://doi.org/10.1016/j.apenergy.2017.10.089.

[27] C. Sherrington and D. Moran, "Modelling farmer uptake of perennial energy crops in the UK," Energy Policy, vol. 38, no. 7, pp. 3567-3578, 2010. https://doi.org/10.1016/j.enpol.2010.02.034.

[28] R. Danielis, M. Scorrano, M. Giansoldati, and S. Alessandrini, "The Economic Case for Electric Vehicles in Public Sector Fleets: An Italian Case Study," World Electric Vehicle Journal, vol. 11, no. 1, 2020. http://doi.org/10.3390/wevj11010022.

[29] A. M. Pavan, V. Lughi, and M. Scorrano, "Total Cost of Ownership of electric vehicles using energy from a renewable-based microgrid," in 2019 IEEE Milan PowerTech, 2019, pp. 1-6. http://doi.org/10.1109/PTC.2019.8810736.

[30] R. Riyanto, S. A. Riyadi, C. Nuryakin, and N. W. G. Massie, "Estimating the Total Cost of Ownership (TCO) of Electrified Vehicle in Indonesia," in 2019 6th International Conference on Electric Vehicular Technology (ICEVT), 2019, pp. 88-99. http://doi.org/10.1109/ICEVT48285.2019.8994030.

[31] P. Kumar and S. Chakrabarty, "Total Cost of Ownership Analysis of the Impact of Vehicle Usage on the Economic Viability of Electric Vehicles in India," Transportation Research Record, vol. 2674, no. 11, pp. 563-572, 2020. https://doi.org/10.1177/0361198120947089.

[32] M. Ayuso, J. M. Bravo, and R. Holzmann, "Getting life expectancy estimates right for pension policy: period versus cohort approach," Journal of Pension Economics and Finance, vol. 20, no. 2, pp. 212-231, 2021. http://doi.org/10.1017/S1474747220000050.

[33] M. Beltran, "Deepening the uncertainty dimension of environmental Life Cycle Assessment: addressing choice, future and interpretation uncertainties," Leiden University, 2018.

[34] H. Schmidt, U. Mathis, and N. Wichmann, Economic Viability of Second Life Applications of Lithium-ion Traction Batteries Logo hier! 2017.

[35] A. P. Vora et al., "Design-space exploration of series plug-in hybrid electric vehicles for medium-duty truck applications in a total cost-of-ownership framework," Applied Energy, vol. 202, pp. 662-672, 2017. https://doi.org/10.1016/j.apenergy.2017.05.090.

[36] T. B. Indonesia, "Top Brand Index Fase 12021 Kategori Kendaraan," 2021. https://www.topbrand-award.com/en/.

[37] P. Louca et al., "Modest effects of dietary supplements during the COVID-19 pandemic: insights from 445850 users of the COVID-19 Symptom Study app," (in eng), BMJ nutrition, prevention \& health, vol. 4, no. 1, pp. 149-157, 2021. http://doi.org/10.1136/bmjnph-2021-000250.

[38] M. W. D. Utami, Y. Yuniaristanto, and W. J. J. O. S. I. Sutopo, "Adoption Intention Model of Electric Vehicle in Indonesia," vol. 19, no. 1, pp. 70-81, 2020. https://doi.org/10.25077/josi.v19.n1.p70-81.2020.

[39] T. Eccarius and C.-C. Lu, "Adoption intentions for micro-mobility - Insights from electric scooter sharing in Taiwan," Transportation Research Part D: Transport and Environment, vol. 84, p. 102327, 2020. https://doi.org/10.1016/j.trd.2020.102327. 
[40] P. Prevedouros and L. Mitropoulos, "Impact of Battery Performance on Total Cost of Ownership for Electric Drive Vehicle," in 2018 21st International Conference on Intelligent Transportation Systems (ITSC), 2018, pp. 1155-1160. http://doi.org/10.1109/ITSC.2018.8569439.

[41] D. Kong, Q. Xia, Y. Xue, and X. Zhao, "Effects of multi policies on electric vehicle diffusion under subsidy policy abolishment in China: A multi-actor perspective," $\begin{array}{lllll}\text { Applied Energy, } & \text { vol. } 266, & \text { p. }\end{array}$ https://doi.org/10.1016/j.apenergy.2020.114887.

[42] F. Kleiner and H. E. Friedrich, "Maintenance \& repair cost calculation and assessment of resale value for different alternative commercial vehicle powertrain technologies," 2017.

[43] Z. Wadud, "Fully automated vehicles: A cost of ownership analysis to inform early adoption," Transportation Research Part A: Policy and Practice, vol. 101, pp. 163176, 2017. https://doi.org/10.1016/j.tra.2017.05.005.

[44] S. Moon and D.-J. Lee, "An optimal electric vehicle investment model for consumers using total cost of ownership: A real option approach," Applied Energy, vol. 253, p. 113494, 2019. https://doi.org/10.1016/j.apenergy.2019.113494.

[45] R. Finesso, D. Misul, E. Spessa, and M. Venditti, "Optimal Design of Power-Split HEVs Based on Total Cost of Ownership and CO2 Emission Minimization," Energies, vol. 11, no. 7, 2018. https://doi.org/10.3390/en11071705.

[46] J. Catton, C. Wang, S. Sherman, M. Fowler, and R. Fraser, "Extended range electric vehicle powertrain simulation, and comparison with consideration of fuel cell and metal-air battery," SAE Technical Paper0148-7191, 2017.

[47] H. Dittus, U. Kugler, and V. Kolarova, "Economic and Environmental Viability of using a PV plant as an energy source for battery electric vehicles," 2017.

[48] I. Mareev and D. U. Sauer, "Energy Consumption and Life Cycle Costs of Overhead Catenary Heavy-Duty Trucks for Long-Haul Transportation," Energies, vol. 11, no. 12, 2018. https://doi.org/10.3390/en11123446.

[49] H. Wang, Y. Huang, and A. Khajepour, "Cyber-Physical Control for Energy Management of Off-Road Vehicles With Hybrid Energy Storage Systems," IEEE/ASME Transactions on Mechatronics, vol. 23, no. 6, pp. 2609-2618, 2018. https://doi.org/10.1109/TMECH.2018.2832019.

[50] P. Lebeau, C. Macharis, and J. Van Mierlo, "How to Improve the Total Cost of Ownership of Electric Vehicles: An Analysis of the Light Commercial Vehicle Segment," World Electric Vehicle Journal, vol. 10, no. 4, 2019. https://doi.org/10.3390/wevj10040090. 